\title{
Zn-Pb ore-forming processes in the McArthur Basin and Lawn Hill Platform (Australia): Insights from lead isotopes and trace elements in sulphides
}

\author{
JOSÉPHINE GIGON ${ }^{1}$, ANTONIN RICHARD ${ }^{1}$, JULIEN \\ MERCADIER $^{1}$, ETIENNE DELOULE ${ }^{2}$, IRVINE R. \\ ANNESLEY $^{1}$, ANDREW WYGRALAK ${ }^{3}$ AND ROGER \\ SKIRROW ${ }^{4}$ \\ ${ }^{1}$ Université de Lorraine - CNRS - CREGU - GeoRessources \\ ${ }^{2}$ CRPG-CNRS-UL \\ ${ }^{3}$ Northern Territory Geological Survey \\ ${ }^{4}$ Geoscience Australia \\ Presenting Author: antonin.richard@univ-lorraine.fr
}

Minor and trace elements in sphalerite and galena can be useful indicators for ore-forming processes in $\mathrm{Zn}-\mathrm{Pb}$ mineral systems, besides their economic significance as potential byproducts. Lead isotopes in galena provide valuable constraints on the number, nature and age of the lead sources as well as on the timing of lead mineralisation. Here, sphalerite and galena from the giant McArthur River (HYC) Zn-Pb deposit and nearby prospects or deposits (Myrtle and Caranbirini) of the Batten Fault Zone in the Proterozoic McArthur Basin, and from the Walford Creek deposit in the nearby Proterozoic Lawn Hill Platform (Australia), have been sampled. The successive sulphide generations were analysed by in situ Laser Ablation Inductively Coupled Plasma - Mass Spectrometry (LA-ICP-MS) in order to determine their minor and trace element content, and by Secondary Ion Mass Spectrometry (SIMS) for their lead isotopic composition. Taking into account previous investigation at $\mathrm{HYC}[1]$, the $\mathrm{Pb}$ isotope composition of galena lies along three distinct trends whose significance in terms of $\mathrm{Pb}$ sources, mixing trends, secondary isochrons and growth curves will be discussed. $\mathrm{The} \mathrm{Pb}$ isotope composition indicates model ages in the ca. 1640$1300 \mathrm{Ma}$ interval and possible relationships between mineralisation and major geodynamic events in the area (e.g. Isan, Albany-Fraser and Musgravian orogenies). The composition of trace elements in sulphides highlights the potential for critical element resources (e.g. Sb, In, Ge, Ga). The composition of sphalerite yields decreasing formation temperature in the successive sphalerite generations (from ca. $220^{\circ} \mathrm{C}$ to less than $100^{\circ} \mathrm{C}$ ). The relationship between trace elements, $\mathrm{Pb}$ isotopes, mineral paragenesis, proximity to major faults and metal tonnage will be discussed in order to highlight the general and local ore-forming processes in the investigated area.

[1] Gigon, Deloule, Mercadier, Huston, Richard, Annesley, Wygralak, Skirrow, Mernagh, Masterman (2020), Geology 48, 478-482. 